\title{
Racial discrimination in pain management*
}

\author{
A discriminação racial no tratamento da dor \\ Maria Clara Giorio Dutra Kreling ${ }^{1}$, Cibele Andrucioli de Mattos Pimenta², Mara Lúcia Garanhani ${ }^{1}$
}

${ }^{*}$ Received from the Department of Nursing, State University of Londrina, Londrina PR, Brazil.

\section{ABSTRACT}

BACKGROUND AND OBJECTIVES: The vulnerability of certain races and ethnicities may be worsened by the subjectivity of pain. So, this study aimed at identifying whether there has been racial discrimination in pain control by health professionals.

CONTENTS: This is a literature review and queried databases were: PubMed/Medline, LILACS, SciELO, Cochrane, EMBASE, SCOPUS and psycINFO with keywords in English and Portuguese: pain-dor and race-raça or ethnic-etnia, analgesiaanalgesia, prejudice/discrimination-discriminação, prescriptions drug-prescrição médica. From 3216 articles, 45 were selected. Five were included after manual search, in a total of 50 articles.

CONCLUSION: No study was carried out in Brazil and 96\% are from the United States. Studies are of the cross sectional and cohort type. Most researched races/ethnicities were black and white, followed by Hispanic and Asian. Most common outcomes were: access to treatment and analgesic prescription. Racial discrimination was identified in $74 \%$ of studies, being blacks the most discriminated race.

Keywords: Analgesia, Discrimination, Ethnicity, Pain, Race.

\section{RESUMO}

JUSTIFICATIVA E OBJETIVOS: A vulnerabilidade de determinadas raças e etnias, pode ser agravada pela subjetividade da dor. Portanto, o objetivo deste estudo foi identificar se há discriminaçáo racial no controle da dor pelos profissionais de saúde. CONTEÚDO: Trata-se de uma revisão de literatura, e as bases de dados consultadas foram: PubMed/Medline, LILACS, SciELO, Cochrane, EMBASE, SCOPUS e psycINFO com palavraschaves em inglês e português: pain-dor and race-raça or ethnic-et-

1. State University of Londrina, Department of Nursing, Londrina, PR, Brazil.

2. University of São Paulo, School of Nursing, São Paulo, SP, Brazil.

Submitted in January 15, 2014.

Accepted for publication in August 22, 2014.

Conflict of interests: none.

Correspondence to:

Maria Clara Giorio Dutra Kreling

Rua Tibagi, 529 - Vila Recreio

86025-270 Londrina, PR, Brasil.

E-mail: mclara@uel.br

(c) Sociedade Brasileira para o Estudo da Dor nia, analgesia-analgesia, prejudiceldiscrimination-discriminação, prescriptions drug-prescrição médica. De 3.216 artigos, 45 foram selecionados. $\mathrm{Na}$ busca manual, cinco foram incluídos, totalizando 50 artigos.

CONCLUSÂO: Nenhum estudo foi realizado no Brasil e $96 \%$ sáo dos Estados Unidos. Os estudos são do tipo transversal e corte. As raças/etnias mais pesquisadas foram a negra e a branca, seguidas dos hispânicos e asiáticos. Os desfechos mais usados foram: acesso ao tratamento e a prescrição de analgésicos. A discriminaçáo racial foi identificada em $74 \%$ dos estudos, sendo a raça negra a mais discriminada.

Descritores: Analgesia, Discriminação, Dor, Raça, Etnia.

\section{INTRODUCTION}

Pain is an experience bringing losses of different forms and magnitudes; its relief has to be considered a right for those feeling it and a duty for those managing it; however, this is not always satisfactorily done ${ }^{1}$.

Among racial and ethnic minorities there is description of differences in quality when managing pain and this may affect health status and quality of life. The American Academy of Pain Medicine and the American Medical Association state that differences in medical care based on unchangeable characteristics such as age, gender and race have to be avoided ${ }^{2}$.

The vulnerability of certain races and ethnicities may be worsened by the subjectivity of pain, the expression of which depends on those feeling it. Studies on the subject are a major advance in the understanding of racial discrimination when managing pain, and health care policies need to develop actions for the adequate assistance to vulnerable populations.

So, this study aimed at identifying racial discrimination in pain control by health professionals.

\section{CONTENTS}

The following electronic databases were queried: Pubmed/Medline, Latin American Literature in Health Sciences (LILACS), Scientific Electronic Library Online (SciELO), Cochrane, EMBASE.com, SCOPUS and psycINFO. The following keywords, standardized in MESH and DeCs, were used: pain-dor and raceraça or ethnic-etnia, and analgesia-analgesia. To further refine the search, the following terms were added to these combinations: prejudice, discrimination, disparities and prescriptions drug. In addition to electronic databases search, we carried out manual search on initially identified publications. No limit date was 
established to obtain a maximum number of articles regarding relevant subjects.

PICO strategy was used to search articles in PubMe/Medline, which means Patient, Intervention, Comparison, Outcome. In our review we have used the keyword "Pain" for Patient, "Race" for Intervention and "Treatment" for Outcome. In a different search attempt we have used the keyword "Analgesia" for Outcome.

Inclusion criteria were: quantitative studies evaluating racial discrimination in pain control and exclusion criteria were studies related to patients' response to pain management according to race. Search flowchart is shown in figure 1.

Titles and abstracts of all identified articles by electronic search

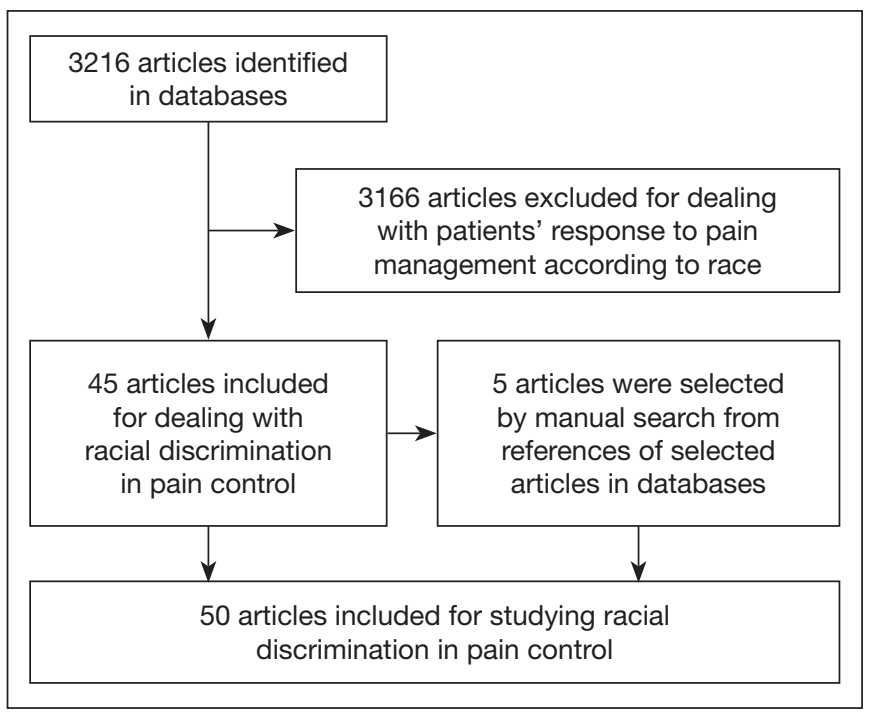

Figure 1. Flowchart of included and excluded studies were reviewed ( $\mathrm{n}=3216)$ and 45 were selected. Manual search has included 5, in a total of 50 articles.

Analyzed aspects were: publication date, country where the study was carried out, studied races, study design, outcomes, level of evidence and major results. Some of these aspects are shown in table 1.

There have been 25 different compositions of racial/ethnic groups among the 50 studies. Blacks and whites were included in most groups (43/50). Methodological designs were predominantly transversal (31/50) and cohort (19/50). Among transversal studies, 15 have evaluated medical records.

There has been predominance (41/50) of studies with control of variables, being sociodemogragphic (35/50) and health insurance $(14 / 50)$ the most widely controlled variables. Analgesics prescription was used as outcome by most studies (29/50).

Racial discrimination has influenced pain control in $4 \%$ of selected studies. Among those evaluating the black race and other races/ethnicities $(\mathrm{n}=43), 24$ have shown discrimination for blacks (55.8\%), and among those exclusively evaluating blacks and whites $(\mathrm{n}=17), 12$ have reported discrimination for blacks. Hispanics were compared to other races/ethnicities in 30 studies and discrimination for this ethnicity was found in 16 studies (53.33\%).

Racial discrimination in pain control seems to be a relatively recent concern among pain researchers, considering that only as from the 1990s studies are proliferating. During the 1990s, in the United States, several professional organizations, such as the World Health Organization, the Agency for Health Policy and Research Care, the American Pain Society and the Society of Oncology Nursing have carried out major efforts to direct discussions about pain management ${ }^{53}$. There is concern with racial discrimination in this country and this is confirmed by the major

Table 1. Summary of major aspects of selected articles

\begin{tabular}{|c|c|c|c|}
\hline Authors & $\begin{array}{l}\text { Methodologi- } \\
\text { cal Design }\end{array}$ & Outcome & Major results \\
\hline Strogatz ${ }^{3}$ & Transversal & Access to health services & $\begin{array}{l}49 \% \text { of blacks and } 27 \% \text { of whites have never visited a physician } \\
\text { due to pain }\end{array}$ \\
\hline Cleeland et al. ${ }^{4}$ & Transversal & $\begin{array}{l}\text { Matching of pain intensity and } \\
\text { analgesic potential }\end{array}$ & $\begin{array}{l}\text { Centers treating predominantly blacks and Hispanics had three } \\
\text { times more chance of inadequately treating pain as compared to } \\
\text { centers treating whites }\end{array}$ \\
\hline $\begin{array}{l}\text { Vangen, Stoltenberg } \\
\& \text { Schei }^{5}\end{array}$ & Transversal & Epidural analgesia & $\begin{array}{l}\text { Pakistani females had three times more chance of not receiving } \\
\text { analgesia as compared to Norwegian patients. }\end{array}$ \\
\hline $\begin{array}{l}\mathrm{Ng} \text {, Dimsdale, } \\
\text { Rollnik et al. }{ }^{6}\end{array}$ & Transversal & Morphine prescription & Significantly higher for blacks and whites as compared to Hispanics \\
\hline Bernabei et al. ${ }^{7}$ & Transversal & Analgesics administration & $\begin{array}{l}\text { Blacks had higher chance of being undertreated as compared to } \\
\text { whites }\end{array}$ \\
\hline Morrison et al. ${ }^{8}$ & Transversal & Opioids availability & $\begin{array}{l}\text { Pharmacies in non-white regions have significantly lower chance of } \\
\text { storing opioids as compared to white regions }\end{array}$ \\
\hline Weisse et al. ${ }^{9}$ & Transversal & Analgesics prescription & $\begin{array}{l}\text { Male physicians have prescribed more to whites than to blacks and } \\
\text { female physicians higher doses for blacks }\end{array}$ \\
\hline Choi et al. ${ }^{10}$ & Transversal & Analgesics administration & Whites received better analgesia than blacks \\
\hline Riley, Gilbert \& Heft ${ }^{11}$ & Transversal & Access to health services & $\begin{array}{l}\text { More white non-Hispanic and black males have visited health servi- } \\
\text { ces as compared to black females }\end{array}$ \\
\hline Singer, Thode ${ }^{12}$ & Transversal & Analgesics administration & There has been no significant difference among races/ethnicities \\
\hline
\end{tabular}


Table 1. Summary of major aspects of selected articles - continuation

\begin{tabular}{|c|c|c|c|}
\hline Authors & $\begin{array}{l}\text { Methodologi- } \\
\text { cal Design }\end{array}$ & Outcome & Major results \\
\hline $\begin{array}{l}\text { Tamayo-Sarver et } \\
\text { al. }{ }^{13}\end{array}$ & Transversal & Opioids prescription & There has been no significant difference among races/ethnicities \\
\hline $\begin{array}{l}\text { Weisse, Sorum e } \\
\text { Dominguez }^{14}\end{array}$ & Transversal & Opioids prescription & $\begin{array}{l}\text { Male physicians have prescribed higher doses for whites than for } \\
\text { blacks and female physicians for blacks. }\end{array}$ \\
\hline $\begin{array}{l}\text { Tamayo-Sarver et } \\
\text { al. }^{15}\end{array}$ & Transversal & Analgesics prescription & $\begin{array}{l}\text { There has been lower chance of being prescribed to blacks as } \\
\text { compared to whites }\end{array}$ \\
\hline Rust et al. ${ }^{16}$ & Transversal & Epidural analgesia & $\begin{array}{l}\text { Analgesia rates were lower for black, Hispanic and Asian females } \\
\text { as compared to white and non-Hispanic females }\end{array}$ \\
\hline $\begin{array}{l}\text { Gerson, Emond \& } \\
\text { Camargo }^{17}\end{array}$ & Transversal & Analgesics administration & There has been no significant difference among races/ethnicities \\
\hline $\begin{array}{l}\text { Adams, Armstrong, } \\
\text { Erstad }^{18}\end{array}$ & Transversal & Morphine prescription & There has been no significant difference among races/ethnicities \\
\hline Portenoy et al. ${ }^{19}$ & Transversal & $\begin{array}{l}\text { Visit to physician and analge- } \\
\text { sics prescription }\end{array}$ & $\begin{array}{l}\text { Significantly less Hispanics as compared to whites and blacks } \\
\text { have visited the physician and blacks had higher chance as com- } \\
\text { pared to whites or Hispanics of having analgesics prescribed }\end{array}$ \\
\hline $\begin{array}{l}\text { Atherton, Feeg \& } \\
\text { El-Adham }{ }^{20}\end{array}$ & Transversal & Epidural analgesia & $\begin{array}{l}\text { Hispanic females had twice more chance of not receiving anal- } \\
\text { gesia as compared to non-Hispanic females }\end{array}$ \\
\hline $\begin{array}{l}\text { McNeill, Sherwood \& } \\
\text { Starck }^{21}\end{array}$ & Transversal & $\begin{array}{l}\text { Pain intensity, patients' satis- } \\
\text { faction }\end{array}$ & $\begin{array}{l}\text { Non-whites had significantly more severe pain and lower satis- } \\
\text { faction scores with pain management as compared to whites }\end{array}$ \\
\hline Vallerand et al. ${ }^{22}$ & Transversal & Pain intensity, functional status & $\begin{array}{l}\text { Blacks have reported more severe pain and worse functional and } \\
\text { mood status as compared to whites }\end{array}$ \\
\hline Taylor et al. ${ }^{23}$ & Transversal & Access to services and therapy & $\begin{array}{l}\text { More imaging tests were recommended for whites. Whites and } \\
\text { Asians had higher chance of having surgical indication as com- } \\
\text { pared to blacks and Hispanics }\end{array}$ \\
\hline Nguyen et al. ${ }^{24}$ & Transversal & Access to therapy & $\begin{array}{l}\text { Hispanics had significant less chance of visiting a pain service as } \\
\text { compared to whites and blacks }\end{array}$ \\
\hline Green et al. ${ }^{25}$ & Transversal & Availability of analgesics & $\begin{array}{l}\text { Areas with predominance of whites had higher chance of analge- } \\
\text { sics as compared to areas of ethnic minorities }\end{array}$ \\
\hline Chen et al. ${ }^{26}$ & Transversal & Opioids prescription & $\begin{array}{l}\text { Whites had higher chance of receiving analgesics as compared } \\
\text { to blacks }\end{array}$ \\
\hline Reyes-Gibby et al. ${ }^{27}$ & Transversal & Pain intensity & $\begin{array}{l}\text { Non-Hispanic and Hispanic blacks had higher risk of having se- } \\
\text { vere pain as compared to non-Hispanic whites. }\end{array}$ \\
\hline Staton et al. ${ }^{28}$ & Transversal & $\begin{array}{l}\text { Difference between physicians } \\
\text { and patients estimate of pain }\end{array}$ & $\begin{array}{l}\text { Physicians have twice the chance of underestimating pain of bla- } \\
\text { cks as compared to other races }\end{array}$ \\
\hline Pletcher et al. ${ }^{29}$ & Transversal & Opioids prescription & $\begin{array}{l}\text { Whites had higher chance of receiving opioids as compared to } \\
\text { Hispanic blacks or Asians }\end{array}$ \\
\hline Cohen et al. ${ }^{30}$ & Transversal & Acess to dentist & Dental service access was more difficult for Hispanics \\
\hline Edwards ${ }^{31}$ & Transversal & $\begin{array}{l}\text { Perception of racial discrimi- } \\
\text { nation }\end{array}$ & $\begin{array}{l}\text { Higher perception for blacks as compared to whites was signi- } \\
\text { ficant }\end{array}$ \\
\hline Quazi S et al. ${ }^{32}$ & Transversal & Analgesics administration & $\begin{array}{l}\text { There has been no difference among blacks, whites and Hispa- } \\
\text { nics }\end{array}$ \\
\hline $\begin{array}{l}\text { Epps, Ware e } \\
\text { Packard }^{33}\end{array}$ & Transversal & Analgesics wait time & Hispanics have waited longer as compared to Americans \\
\hline $\begin{array}{l}\text { Todd, Samaroo e } \\
\text { Hoffman }^{34}\end{array}$ & Retrospective & Analgesics administration & $\begin{array}{l}\text { Hispanics had twice more chance of not receiving analgesics as } \\
\text { compared to hon-Hispanic whites }\end{array}$ \\
\hline Mc Donald ${ }^{35}$ & Retrospective & Opioids administration & $\begin{array}{l}\text { Whites have received significantly more opioids as compared to } \\
\text { blacks and Hispanics. }\end{array}$ \\
\hline $\mathrm{Ng} \mathrm{B}$ et al..$^{36}$ & Retrospective & Morphine prescription & $\begin{array}{l}\text { Significantly lower for blacks as compared to Hispanics and whi- } \\
\text { tes }\end{array}$ \\
\hline Benson et al. ${ }^{37}$ & Retrospective & $\begin{array}{l}\text { Analgesics administration and } \\
\text { other interventions }\end{array}$ & $\begin{array}{l}\text { Interventions were significantly more required for whites as com- } \\
\text { pared to non-whites }\end{array}$ \\
\hline $\begin{array}{l}\text { Karpman, Del Mar } \\
\& \text { Bay }^{38}\end{array}$ & Retrospective & Analgesics prescription & $\begin{array}{l}\text { There has been no significant difference between whites and } \\
\text { Hispanics }\end{array}$ \\
\hline
\end{tabular}


Table 1. Summary of major aspects of selected articles - continuation

\begin{tabular}{|c|c|c|c|}
\hline Authors & $\begin{array}{l}\text { Methodologi- } \\
\text { cal Design }\end{array}$ & Outcome & Major results \\
\hline Todd et al. ${ }^{36}$ & Retrospective & Analgesics administration & $\begin{array}{l}\text { Blacks had lower chance of receiving analgesics as compared to } \\
\text { whites }\end{array}$ \\
\hline Heins et al. ${ }^{41}$ & Retrospective & Dose of prescribed opioids & Significantly lower for blacks as compared to whites \\
\hline Bijur et al. ${ }^{43}$ & Retrospective & Analgesics administration & There has been no difference between races/ethnicities \\
\hline Ranasinghe et al. ${ }^{44}$ & Retrospective & $\begin{array}{l}\text { Health Insurance, use of inter- } \\
\text { ventionist units }\end{array}$ & $\begin{array}{l}\text { There has been no difference between indigenous and non-indi- } \\
\text { genous }\end{array}$ \\
\hline $\begin{array}{l}\text { Todd, Lee \& } \\
\text { Hoffman }^{45}\end{array}$ & Prospective & $\begin{array}{l}\text { Difference between physi- } \\
\text { cians' pain estimate and pa- } \\
\text { tients' reports }\end{array}$ & There has been no significant difference between races/ethnicities \\
\hline Carey e Garrett ${ }^{48}$ & Prospective & $\begin{array}{l}\text { Radiograph and imaging exa- } \\
\text { ms }\end{array}$ & $\begin{array}{l}\text { Blacks had lower chance of receiving radiographs or imaging exa- } \\
\text { ms as compared to whites }\end{array}$ \\
\hline Green et al. ${ }^{49}$ & Prospective & $\begin{array}{l}\text { Management according to } \\
\text { type of pain }\end{array}$ & There has been no significant difference between races/ethnicities \\
\hline Rabow \& Dibble ${ }^{50}$ & Prospective & $\begin{array}{l}\text { Pain report and analgesics } \\
\text { prescription }\end{array}$ & $\begin{array}{l}\text { Blacks have reported more severe pain as compared to whites. } \\
\text { There has been no significant difference in opioid prescription }\end{array}$ \\
\hline Miner et al..$^{51}$ & $\begin{array}{l}\text { Prospective } \\
\text { observational }\end{array}$ & $\begin{array}{l}\text { Difference between physicians } \\
\text { and patients pain estimate }\end{array}$ & $\begin{array}{l}\text { Perception of exaggerated symptoms was higher among Ameri- } \\
\text { cans. }\end{array}$ \\
\hline Bijur et al. ${ }^{52}$ & Prospective & Analgesics administration & There has been no significant difference between races/ethnicities \\
\hline
\end{tabular}

attention this subject is receiving from Health Services in the last 10 years $^{2}$. It is observed that, in spite of the increasing concern with pain management in the last decades, the prevalence of studies with outcomes of racial discrimination in pain control has also increased.

Lack of differentiation between race and ethnicity is observed because many studies refer to those terms as synonyms. The predominant notion of race in biomedical research has been understood as phenotypic characteristics such as color of skin and facial characteristics which may be used to classify people in genetic subgroups. The concept of ethnicity has been suggested as race alternative aiming at not having a strictly biological connotation, implying that groups may vary with regard to culture and biological pattern ${ }^{54}$.

The difference between these constructions is very often blurred, leading researchers to consider them in a single race/ethnicity dimension, which is also justified because data are in general collected by self-report, and several respondents consider both terms as synonyms ${ }^{54}$.

As to the term "Hispanic", the National Health Institute of the United States has reported that the terms "Hispanics and Latinos" are used by researchers to all people descendant of Spaniards, when such people may come from Cuba, Mexico, Puerto Rico, South or Central America or other Spanish cultures. It has also to be stressed that authors do not justify their choices, do not present any pre-established criteria and are not guided by a standardized classification. In spite of that, it is a mistake to conclude that for not being scientific classifications, but rather built and reinforced by social rules, race and ethnicity are of no value for research ${ }^{55}$.

Most are transversal studies and from them, 50\% have used medical records data. In this case it is difficult to determine whether patients requested less medication for pain, or if patients would simply refer less pain. So, pain investigators' challenge is to determine when and why differences exist.

Notwithstanding confusion variables control in most studies, racial discrimination is described by $74 \%$ of them; however it is understood that such result has to be considered at the light of the extreme difficulty to isolate race/ethnicity effects from the socioeconomic position which, in the United States, are closely intermingled ${ }^{56}$. Outcomes vary, indicating a limitation in the comparison of results.

Black race was discriminated the most $(55.8 \%)$, followed by Hispanics $(53.3 \%)$. These results are similar to those observed by two literature reviews ${ }^{53-57}$.

Racial discrimination in pain management may be related to several issues. Pain expression and interpretation are affected by their meaning. Meaning and behavior may be associated to cultural rules, and perception and communication may be impaired when health professional and patient ethnicities are different. The ethnic 
stereotype may also interfere with health professionals' ability to reliably evaluate pain. So, for a number of reasons, professionals are at risk of undervaluing pain of patients of other cultures.

Although differences in pain management based on race and ethnicity are common themes in pain studies, there is little evidence to explain why these differences exist ${ }^{24}$. Possible explanations include heath caregivers' racism, language and cultural barrier impairing communication, socioeconomic factors which affect ethnic minorities and gaps in the understanding how to reliably evaluate pain. Until such aspects are not further understood, it will be difficult to develop strategies to eliminate ethnic and racial differences in pain management ${ }^{2}$.

Research on culturally and linguistically-sensitive pain evaluation tools and studies about quality assistance of social and ethnic minorities experiencing pain are needed ${ }^{24}$. Authors suggest that one initiative to minimize racial discrimination in pain management could be the implementation of protocols to assist patients in health services ${ }^{58}$. Another important aspect to be considered is the need for discussions during health professionals' qualification, allowing the analysis of prejudices influencing assistance provided.

A limitation of this study might be the fact that studies were almost totally carried out in the United States, restricting a broader analysis about possible differences in assistance to painful patients according to their racial/ethnic condition.

\section{CONCLUSION}

Racial discrimination was identified in most selected studies, being the black race the most discriminated, followed by Hispanics. Most common outcome was related to analgesics prescription. It was observed that caregivers' behavior contributes for ethnic/racial discrimination in pain management. It is believed that the findings of this study may be correlated to the assistance to painful patients in Brazil, considering the racial diversity of our country. Our results point to the need for further studies on this subject in other countries different from the United States and to the importance of the reflection about the influence of cultural differences on care assistance during the qualification of health professionals.

\section{REFERENCES}

1. Lebovits A. The Ethical Implications of Racial Disparaties in Pain: Are Some of Us More Equal? Pain Med. 2005 6(1).

2. Green C, Todd KH, Lebovits A, Francis M. Disparities in pain: ethical issues. Pain Med. 2006;7(6):530-3.

3. Strogatz DS. Use of medical care for chest pain: differences between blacks and whites. Am J Public Health. 1990;80(3):290-4.

4. Cleeland CS, Gonin R, Hatfield AK, Edmonson JH, Blum RH, Stewart JA, et al. Pain and its treatment in outpatients with metastatic cancer. N Engl J Med. 1994;330(9):592-6

5. Vangen S, Stoltenberg C, Schei B. Ethnicity and use of obstetrical analgesia: do Pakistani women receive inadequate pain relief in labour? Ethn Health. 1996;1(2):161-7.

6. $\mathrm{Ng} \mathrm{B}$, Dimsdale JE, Rollnik JD, Shapiro H. The effect of ethnicity on prescriptions for patient-controlled analgesia for post-operative pain. Pain. 1996;66(1):9-12.

7. Bernabei R, Gambassi G, Lapane K, Landi F, Gatsonis C, Dunlop R, et al. Management of pain in elderly patient with cancer. JAMA. 1998;279(23):1877-82.

8. Morrison RS, Wallenstein S, Natale DK, Senzel RS, Huang L. 'We don't carry that"- failure of pharmacies in predominantily nonwhite neighborhoods to stock opioid analgesics. N Engl J Med. 2000;342(14):1023-6.

9. Weisse CS, Sorum PC, Sanders KN, Syat BL. Do gender and race affect decisions about pain management? J Gen Intern Med. 2001;16(4):211-7.

10. Choi DM, Yate P, Coats T, Kalinda P, Paul EA. Ethnicity and prescription of analgesia in an accident and emergency department: cross sectional study. BMJ. 2000;320(7240):980-1

11. Riley JL 3rd, Gilbert GH, Heft MW. Race/ethnic differences in health care use for orofacial pain among older adults. Pain. 2002;100(1-2):119-30.

12. Singer AJ, Thode HC Jr. National analgesia prescribing patterns in emergency depart ment patients with burns. J Burn Care Rehabil. 2002;23(6):361-5.

13. Tamayo-Sarver JH, Dawson NV, Hinze SW, Cydulka RK, Wigton RS, Albert JM, et al. The effect of race/ethnicity and desirable social characteristics on physicians decisions to prescribe opioid analgesics. Acad Emerg Med. 2003;10(11):1239-48.

14. Weisse CS, Sorum PC, Dominguez RE. The influence of gender and race on physicians' pain management decisions. J Pain. 2003;4(9):505-10.

15. Tamayo-Sarver JH, Hinze SW, Cydulka RK, Baker DW. Racial and ethnic disparities in emergency department analgesic prescription. Am J Public Health. 2003;93(12):2067-73.

16. Rust G, Nembhard WN, Nichols M, Omole F, Minor P, Barroso G, et al. Racial and ethnic disparaties in the provision of epidural analgesia to Georgia Medicaid beneficiaries during labor and delivery. Am J Obstet Gynecol. 2004;191(2):456-62.

17. Gerson LW, Emond JA, Camargo CA Jr. US emergency department visits for hip fracture, 1992-2000. Eur J Emerg Med. 2004;11(6):323-8.

18. Adams RJ, Armstrong EP, Erstad BL. Prescribing and self-administration of morphine in Hispanic and non Hispanic Caucasian patients treated with patient-controlled analgesia. J Pain Palliat Care Pharmacother. 2004;18(2):29-38.

19. Portenoy RK, Ugarte C, Fuller I, Haas G. Population-based survey of pain in the United States: differences among white, African American, and Hispanic subjects. J Pain. 2004;5(6):317-28.

20. Atherton MJ, Feeg VD, El-Adham AF. Race, ethnicity, and insurance as determinant of epidural use: anlysis of a national sample survey. Nurs Econ. 2004;22(1):6-13.

21. McNeill JA, Sherwood GD, Starck PL. The hidden errors of mismanaged pain: a systems approach. J Pain Symptoms Manage. 2004;28(1):47-58.

22. Vallerand AH, Hasenau S, Templin T, Collins-Bohler D. Disparaties between black and white patients with cancer pain: the effect of perception of control over pain. Pain Med. 2005;6(3):242-50.

23. Taylor BA, Casas-Ganem J, Vaccaro AR, Hilibrand AS, Hanscom BS, Albert TJ. Differences in the work-up and treatment of conditions associated with low back pain by patient gender and ethnic background. Spine. 2005;30(3):359-64.

24. Nguyen M, Ugarte C, Fuller I, Haas G, Portenoy RK. Access to care for chronic pain racial and ethnic differences. J Pain. 2005;6(5):301-14.

25. Green CR, Ndao-Brumblay SK, West B, Washington T. Differences in prescription opioid analgesic availability: comparing minority and white pharmacies across Michigan. J Pain. 2005;6(10):689-99.

26. Chen I, Kurz J, Pasanen M, Faselis C, Panda M, Sataton LJ, et al. Racial differences in opioid use for chronic nonmalignant pain. J Gen Intern Med. 2005;20(7):593-8.

27. Reyes-Gibby CC, Aday LA, Todd KH, Cleeland CS, Anderson KO. Pain in aging community-dwelling adults in the United States: non-Hispanic whites, non-Hispanic blacks, and Hispanics. J Pain. 2007; 8(1):75-84.

28. Staton LJ, Panda M, Chen I, Genao I, Kurz J, Pasanen M, et al. When race matters: disagreement in pain perception between patients and their physicians in primary care. J Natl Med Assoc. 2007;99(5):532-8.

29. Pletcher MJ, Kertesz SG, Kohn MA, Gonzales R. Trends in opioid prescribing by race/ethnicity for patients seeking care in US emergency departments. JAMA. 2008;299(1):70-8

30. Cohen LA, Bonito AJ, Akin DR, Manski RJ, Macek MD, Edwards RR, et al. Toothache pain: a comparison of visits to physicians, emergency departments and dentists. J Am Dent Assoc. 2008;139(9):1205-16.

31. Edwards RR. The association of perceived discrimination with low back pain. J Behav Med. 2008;31(5):379-89.

32. Quazi S, Eberhart M, Jacoby J, Heller M. Are racial disparities in ED analgesia improving? Evidence from a national database. Am J Emerg Med. 2008;26(4):462-4.

33. Epps CD, Ware LJ, Packard A. Ethnic wait time differences in analgesic administration in the emergency department. Pain Manag Nurs. 2008;9(1):26-32.

34. Todd KH, Samaroo N, Hoffman JR. Ethnicity as a risk factor for inadequate emergency department analgesia. JAMA. 1993;269(12):1537-9.

35. Mc Donald DD. Gender and ethnic stereotyping narcotic analgesic administration. Res Nurs Health. 1994;17(1):45-9.

36. Ng B, Dimsdale JE, Shragg GP, Deutsch R. Ethnic differences in analgesic consumption for postoperative pain. Psychosom Med. 1996;58(2):125-9.

37. Benson NH, Sylvain H, Nimmo MJ, Dunn KA, Goodman P, O’Brien K. Influence of demographic variables in prehospital treatment of patients with chest pain. Prehosp Emerg Care. 1997;1(1):19-22.

38. Karpman RR, Del Mar N, Bay C. Analgesia for emergency centers' orthopaedic patients: does an ethnic bias exist? Clin Orthop Relat Res. 1997;334:270-5.

39. Todd KH, Deaton C, D'Adamo AP, Goe L. Ethnicity and analgesic practice. Ann Emerg Med. 2000;35(1):11-6.

40. Fuentes EF, Kohn MA, Neighbor ML. Lack of association between patient ethnicity or race and fracture analgesia. Acad Emerg Med. 2002;9(9):910-5.

41. Heins JK, Heins A, Grammas M, Costello M, Huang K, Mishra S. Disparaties in analgesia and opioid prescribing practices for patients with musculoskeletal pain in the emergency department. J Emerg Nurs. 2006 32(3):219-24. 
42. Glance LG, Wissler R, Glantz C, Osler TM, Mukamel DB, Dick AW. Racial differences in the use of epidural analgesia for labor. Anesthesiology. 2007;106(1):19-28.

43. Bijur P, Bérard A, Esses D, Calderon Y, Gallagher EJ. Race, ethnicity, and management of pain from long-bone fractures: a prospective study of two academic urban emergency departments. Acad Emerg Med. 2008;15(7):589-97.

44. Ranasinghe I, Chew D, Aroney C, Covadarle S, Allen R, Walters D, et al. Differences in treatment and management of indigenous and non-indigenous patients presenting with chest pain: results of the Heart Protection Partnership (HPP) study. Heart Lung Circ. 2009;17(1):32-7.

45. Todd KH, Lee T, Hoffman JR. The effect of ethnicity on physician estimates of pain severity in patients with isolated extremity trauma. JAMA. 1994;271(12):925-8.

46. Bartfield JM, Salluzzo RF, Robak-Raccio N, Verdile VP. Physician and patient factors influencing the treatment of low back pain. Pain. 1997;73(2):209-11.

47. Cleeland CS, Gonin R, Baez L, Loehrer P, Pandya KJ. Pain and treatment of pain in minority patients with cancer. Ann Intern Med. 1997;127(9):813-6.

48. Carey TS, Garrett JM. The relation of race to outcomes and the use of health care services for acute low back pain. Spine. 2003;28(4):390-4

49. Green CR, Anderson KO, Baker TA, Campbell LC, Decker S, Fillingim RB, et al. The unequal burden of pain: confronting racial and ethnic disparities in pain. Pain Med. 2003;4(3):277-94.
50. Rabow MW, Dibble SL. Ethnic differences in pain among outpatients with terminal and end-stage chronic illness. Pain Med. 2005;6(3):235-41.

51. Miner J, Biros MH, Trainor A, Hubbard D, Beltram M. Patient and physician perception as risk factors for oligoanalgesia: a prospective observational study of the relief of pain in the emergency department. Acad Emerg Med. 2006;13(2):140-6.

52. Bijur P, Bérard A, Nestor J, Calderon Y, Davitt M, Gallagher EJ. No racial or ethnic disparity in treatment of long-bone fractures. Am J Emerg Med. 2008;26(3):270-4.

53. Ezenwa MO, Ameringer S, Ward SE, Serlin RC. Racial and ethnic disparities in pain management in the United States. J Nurs Scholarsh. 2006;38(3):225-33.

54. Kaufman JS, Cooper RS. Comentary: considerations for use of racial/ethnic classification in etiologic research. Am J Epidemiol. 2001;154(4):291-8.

55. Laguardia J. O uso da variável "Raça” na Pesquisa em Saúde. Rev Saúde Coletiva 2004;14(2):197-234.

56. Burguess DJ, van Ryn M, Crowley-Matoka M, Malat J. Understanding the provider contribution to race/ethnicity disparities in pain treatment: insights from dual process models of stereotyping. Pain Med. 2006;7(2):119-34.

57. Bonham VL. Race, ethnicity, and pain treatment: striving to understand the causes and solutions to the disparities in pain treatment. J Law Med Ethics. 2001;29(1):52-68.

58. Cintron A, Morrison RS. Pain and ethnicity in the United States: a systematic review. J Palliat Med. 2006;9(6):1454-73. 